\title{
A Proposed Framework for the Growth of Online Learning Communities
}

\section{Nevine Mahmoud Fayek El Souefi}

Edupedia for Educational Consultancy, Traning, and Curriculum Designing, Egypt.

\begin{abstract}
The abrupt shift to full online learning due to COVID-19, displaced students and teachers, created multiple barriers in teaching and learning, and caused some instructors not being able to build and maintain an online learning community. This situation resulted in students' detachment from their instructor and peers causing lack of motivation and increase of failure chances. First the paper explores the challenges and opportunities of building and online learning community highlighting the needs, and reviewes some past frameworks in the field. Second, a framework proposed identifies four factors that help the growth of online learning communities. Those factors are; teacher presence, social presence, cognitive presence and students' emotional engagement. Further the framework specifies type of actions and activities that teachers/instructors should be adopting throughout the course. The paper adds to the growing knowledge on Coronavirus effects on the educational sector and highlights the need for the efficeint use of technology in education.
\end{abstract}

Keywords: Online learning community; Covid-19; teaching presence; social presence; cognitive presence; emotional engagement. 


\section{Introduction}

With the breakout of COVID 19 in 2020, 195 countries have mandated school closures (UNESCO, 2020) affecting all levels of the educational systems, as there was an abrupt transition to online learning (World Bank, 2020). Most teachers and instructors were not ready for this shift (Middleton, 2020), which increased the possibility of students being disengaged and dropping out (García and Weiss, 2020). Researchers have been informing an increase in students' disengagement and detachment from learning since shifting to full online learning through the pandemic (Duraku \& Hoxha, 2020).

This situation triggered all educational professionals to try to design solutions for this preceding problem. According to Middleton (2020), "Educators, educational researchers, and policymakers have been presented with perhaps the biggest challenge of their careers." The OECD (2020) report marked using platforms to create learning communities and teachers' communication with students as a need for professional development to enhance online learning. This paper is addressing this challenge by proposing a practical framework to build and maintain an online learning community to reduce what Karahalios \& Donath (2003) identify as 'social spaces', and to ensure continuity of learning. The research questions are as follows:

1. What are the factors enhancing online learning communities?

2. How can we build and maintain a successful online learning community?

\section{Literature Review}

The literature review will be first discussing challenges and opportunities for building online communities. Then, reviewing some examples of online learning community frameworks in literature.

\subsection{Building Online Learning Communities: Challenges and Opportunities}

The definition of the term was viewed differently by different researchers. The Office of Learning Technologies (1998) defined it by its components; community, learning, network technology. Community learning can refer to a situation in which learning occurs as a social learning process (Tu and Corry, 2001). A network is defined as a pattern of communications and relationships. They are essential tools for mobilizing community participants around local social issues. Network technology are systems used as a medium of communication that can be synchronous (real time communication) or asynchronous (time-delayed communication) systems (Tu and Corry, 2001).

According to McMillan and Chavis (1986), a sense of community is "a feeling that members have belonging, a feeling that members matter to one another and to the group, and a shared 
faith that members' needs will be met through their commitment to be together" (p.9). Tu and Corry (2001) define it from a social aspect as "a common place where people learn through group activity to define problems affecting them, to decide upon a solution, and to act to achieve the solution" (p.1). They aim towards a learning community that is more than sharing information, where learners apply appropriate information to knowledge construction and advance to the level of a community that learns.

Researchers agree that for online learning to succeed it needs a 'community of learners', where there are social engagements in strong social networks with quantity and quality of interactions (Oliveira, Tinoca, \& Pereira, 2011). On the other hand, compared to traditional classrooms, online education can be a lonely experience due to the separate place and the absence of body language and the interaction atmosphere (Differding, 2003). According to Lambert and Fisher (2013), "Online technologies, when appropriately utilized, can encourage community among distant learners and challenge learners beyond what might be possible in courses without technology." (p.2)

Building an online learning community needs its members to be consistent in enhancing factors that build a community. One of Clark (1998) principles to build an online learning community was that learning communities are not built, but they grow by themselves. $\mathrm{He}$ identified clear guidelines communicated from the beginning and sustained as a must for its growth. Barab et. al (2004) proposed the same idea that online learning communities cannot be constructed. Their development requires facilitation of collaborative relationships that is to be maintained.

\subsection{Frameworks for building online learning communities}

Due to the importance of building an online learning community in technology-based instructions, some frameworks appeared in research identifying and organizing factors that can be implemented to build this community.

Garrison et. al. (2000), provided a conceptual framework that provides the elements for a learning community that support learning experiences. Their framework is consistent with John Dewey's work seeing inquiry as a social activity. They called it the Community of Inquiry (COI). This framework is based on three critical elements in using online asynchronous, text-based communication in higher education; social presence (SP), cognitive presence (CP), and teaching presence (TP).

Blayone et. al. (2017) presented a divergent vision of the Community of Inquiry model (COI), the Fully Online Learning Community (FOLC). FOLC is like COI in being a socialconstructivist learning model with learning constructed as different interactions categorized in several presences. However, FOLC incorporates SP and CP only. It subsumes TP fully within the other presences. This difference emphasizes the idea of community and learners' 
empowerment. In addition, the FOLC adds to SP and CP, digital space as contextual construct that can strengthen SP and CP. The FOLC incorporate several sub-models addressing different layers of the learning experience responding to problems related to higher education.

Khoo and Cowie (2010) designed a practical framework that highlights the appropriate conditions for the development and conduct of online learning communities. The framework represents learning in a strong social learning community as an activity based on five principles that is; mediated, distributed, goal- directed, and participatory. They translated their framework into practice by identifying actions, web-tools, and teaching strategies for each principle.

\section{The Proposed Framework}

From the literature review above we can understand that the growth of an online learning community depends on teachers instilling different community factors by consistent actions and activities throughout the course.

Teaching Presence coming first factor as it is seen as a base that help students develop social presence, and promote students' cognitive presence (Garrison et. al., 2010). Social presence comes next as it is promoted by teachers giving opportunities to share authentic personal and professional elements with the instructor and peers. (Garrison, et. al., 2010). Cognitive presence needs student first to feel social presence and teaching presence. (Garrison \& Cleveland-Innes, 2005). Those three components derive students' emotional engagement and consequently participating in building this sense of community. Those four main factors are enhanced by actions and activities that instructors adopt throughout the course.

The framework is based on tow ideas; the first is identifying main factors that help grow an online community, and the second specific type of actions and activities that teachers should be adopting throughout the course to ensure consistency.

\subsection{Factors for the growth of an online learning community}

\subsubsection{Teachers' Presence}

According to Garrison \& Arbaugh (2007), teaching presence is "as a significant determinant of student satisfaction, perceived learning, and sense of community" (p. 163). Teaching presence has three dimensions; the instructional design and organization, facilitation of discourse, and direct instruction that online instructors "do" (Garrison \& Arbaugh, 2007). Those dimensions promote a pedagogy that engage students thinking, share views consider other views, reflect on their own, rethink previous positions, and integrate new ideas in their cognitive structure. (Shea et. al., 2006). The goal directed collaborative interaction support 
the sense of connectedness between students. Teaching presence promote students' sense of trust, collaboration, shared educational objectives, and support (Garrison et al., 2000). Teachers are to promote high levels of interaction with students, prompt feedback, active roles for learners, a greater emphasis on student cooperation over competitiveness, (Garrison, Anderson et. al. 2000). Teachers' availability to students increase students sense of connectedness. Phirangee, et. al. (2016) found that students felt more connected when instructors took an active role in facilitating discussions. Tomas et. Al. (2015) reported students valued timely feedback and support from teaching staff.

\subsubsection{Social Presence}

Social presence is the ability of participants to establish themselves as real in a virtual environment (Berry, 2019; Garrison et al., 2010). Due to asynchronous environments have less affective communication, some researchers view it as less likely to promote social presence (Short et al., 1976). On the other hand, other researcher argue that the impersonal communication can be 'hyper-personal' (Walther, 1994). Participants in an online learning community can create social presence by showing their identity through verbal immediacy behaviors alone (Richardson \& Swan, 2001). Social presence and sense of community is promoted by students working together in online assignments requiring peer or group work (Waycott et. al., 2013).

\subsubsection{Cognitive Presence}

Cognitive presence refers to the student's ability to reflect, reconstruct, and conform meaning (Berry, 2019; Garrison \&Arbaugh, 2007). Cognitive presence depends on the instructors' ability in reflexive facilitation techniques that provoke Students to question, critique, and reflect in dialogue with peers and driving moments of learning. (Berry, 2019; Garrison et al., 2010). Online content management systems and Web 2.0 web sites provide instructors with opportunities to integrate online resources where students can explore, create, and share their new knowledge encouraging deeper engagement with learning (Jacobs, 2003). Those systems allow for students to be engaged in active, experiential and praxis-oriented learning experiences through scaffolded hands-on activities and experiments embedded in the online modules and tutorials. (Tomus et. Al., 2015).

\subsubsection{Emotional Engagement}

Mahdy (2020) reported the effects of the lockdown on university students. Participants responses identified 'Loss of interest' to be one of the main problems resulting from online learning. Students' emotional engagement is highly influential on students' participation in any learning community (Zappala, 2012). For online environments to facilitate constructivist, collaborative, and student sceptered teaching approaches, instructors have to give attention to fostering student engagement, stimulating intellectual development and building rapport with students. (Beldarrin, 2006) 


\subsection{Types of actions and activities for the growth of an online learning community}

To produce a practical framework for teachers/instructors can easily use in their courses, it has to guide them through with actions taken throughout the learning process that enhance factors building online learning communities. The Framework is based on the idea that feeding the learning process with consistent actions or activities that enhance factors of building an online learning community helps the community to grow (Clark, 1998; Barab, Kling, \& Gray, 2004). The following table summarize some activities and actions taken throughout the course, and match those actions to factors that build online learning communities. It also identifies types of web tools used with different actions. 
Table 1. Actions and Activities throughout the course that enhance factors building online learning communities.

\begin{tabular}{|c|c|c|c|}
\hline $\begin{array}{l}\text { Times of the } \\
\text { course }\end{array}$ & $\begin{array}{l}\text { Actions } \\
\text { Aspects }\end{array}$ & Examples of Activities & $\begin{array}{l}\text { Factor } \\
\text { s }\end{array}$ \\
\hline \multirow{3}{*}{$\begin{array}{l}\text { Before the } \\
\text { beginning of } \\
\text { the course }\end{array}$} & Planning & inquiry activties, authentic real-life research issues, plan resources and & $T P^{*}$ \\
\hline & $\begin{array}{l}\text { Learning \& } \\
\text { Inquiry }\end{array}$ & tasks accordingly. discussions, presentations \& collaborations. & $C P^{*}$ \\
\hline & $\begin{array}{l}\text { Planning } \\
\text { Virtual } \\
\text { spaces }\end{array}$ & $\begin{array}{l}\text { communication plan of consistent times, ways, announcements, } \\
\text { posting and submitting assignments, a community space, and } \\
\text { organise your virtual classroom/platform. }\end{array}$ & $S P^{*}$ \\
\hline \multirow[t]{2}{*}{$\begin{array}{l}\text { At the } \\
\text { beginning of } \\
\text { the course }\end{array}$} & $\begin{array}{l}\text { Introductio } \\
\mathrm{n} \\
\text { activities }\end{array}$ & $\begin{array}{l}\text { students post their personal information. Greetings Post at the } \\
\text { beginning of the course (video/text with instructor's photo) } \\
\text { Ice-breaker activity. }\end{array}$ & $E E^{*}$ \\
\hline & $\begin{array}{l}\text { Set the } \\
\text { scene }\end{array}$ & $\begin{array}{l}\text { Setting guidelines, regulations and clarifying expectations and } \\
\text { deadlines. Collaborating in setting a class community agreements } \\
\text { with students. }\end{array}$ & $\begin{array}{l}E E \\
S P \\
T P\end{array}$ \\
\hline \multirow{8}{*}{$\begin{array}{l}\text { At the } \\
\text { beginning of } \\
\text { the week } \\
\text { At the end of } \\
\text { the week } \\
\text { Ongoing } \\
\text { In } \\
\text { Asynchronou } \\
\text { s tasks }\end{array}$} & Community & share a goal for the week - What do you want to focus on. & $T P$ \\
\hline & meeting & $\begin{array}{l}\text { Weekly updates/prompts to remind students about the } \\
\text { week's topics and how they are to participate. }\end{array}$ & $\begin{array}{l}S P \\
E E\end{array}$ \\
\hline & $\begin{array}{l}\text { Community } \\
\text { meeting }\end{array}$ & $\begin{array}{l}\text { Group reflection, students share their feelings, fears, ...etc. address } \\
\text { the outcomes in your future morning meetings. }\end{array}$ & $\begin{array}{l}S P \\
E E\end{array}$ \\
\hline & $\begin{array}{l}\text { Monitoring } \\
\& \text { Giving } \\
\text { Feedback }\end{array}$ & $\begin{array}{l}\text { Prompt feedback to student queries - Peer feedback - Consistent } \\
\text { monitoring of students achievemtns and giving positive feedback - } \\
\text { informal formative assessment like; checking understanding } \\
\text { frequently. }\end{array}$ & $\begin{array}{l}T P \\
C P\end{array}$ \\
\hline & $\begin{array}{l}\text { Asynchron } \\
\text { ous } \\
\text { Type of } \\
\text { Tasks }\end{array}$ & $\begin{array}{l}\text { generate discussion. Opportunity for students' analyze and share } \\
\text { individual postings in knowledge building activities. Use of } \\
\text { resources and inquiry activates such as; gathering, analyzing, } \\
\text { presenting data, defining issues; and defending conclusions. }\end{array}$ & $\begin{array}{l}T P \\
S P \\
C P\end{array}$ \\
\hline & $\begin{array}{l}\text { Infuse } \\
\text { Teacher's } \\
\text { presence }\end{array}$ & $\begin{array}{l}\text { building in personalized graphics, using pictures or avatars. - Screen } \\
\text { simulations or voice- over presentations is to use Camtasia, Jing, or } \\
\text { Captivate. }\end{array}$ & $T P$ \\
\hline & Support & $\begin{array}{l}\text { Assign office hours. - Have ready a frequently asked questions link - } \\
\text { Answer e.mails promptly. }\end{array}$ & $\begin{array}{l}T P \\
E E\end{array}$ \\
\hline & $\begin{array}{l}\text { Infuse } \\
\text { Collaborati } \\
\text { on }\end{array}$ & $\begin{array}{l}\text { Establish a "virtual hallway" or a discussion forum. Chat and instant } \\
\text { message. Complete collaborative class projects. Foster purposeful } \\
\text { collaboration and dynamic discussions. }\end{array}$ & $\begin{array}{l}S P \\
C P\end{array}$ \\
\hline \multirow{3}{*}{$\begin{array}{l}\text { Ongoing } \\
\text { In } \\
\text { Synchronous } \\
\text { meeting }\end{array}$} & Beginning & $\begin{array}{l}\text { Check-ins:An attention activity } \\
\text { mentoring, monitoring, referring, and linking to students' ideas, }\end{array}$ & $\begin{array}{l}E E \\
T P\end{array}$ \\
\hline & Body & $\begin{array}{l}\text { interacting with students that involves; initiating discussions, asking } \\
\text { probing questions, using humor, using self-disclosure, responding } \\
\text { quickly and frequently, use visuals and concept maps, and create } \\
\text { opportunities for students to share their work. }\end{array}$ & $\begin{array}{l}S P \\
C P \\
E E\end{array}$ \\
\hline & Ending & $\begin{array}{l}\text { Encouraging closure; positive specific feedback after the session, } \\
\text { follow up to what they learned. }\end{array}$ & $\begin{array}{l}T P \\
E E\end{array}$ \\
\hline $\begin{array}{l}\text { At the end of } \\
\text { the term }\end{array}$ & Reflection & Setting personal goals and revising goals. & $E E$ \\
\hline
\end{tabular}




\section{Conclusion}

Establishing learning communities in online courses can solve the problem of students' disengagement and increase success chances. For students to grow the sese of community, teachers and instructors need to be consistent in using online communication tools in engaging students in authentic tasks and activities directed to support the growth of a leaning community. This paper is proposing a practical framework to develop online learning communities from a sociocultural perspective. The framework discusses factors that develop a community; teaching presence, social presence, cognitive presence, and emotional engagement. The framework also proposes the use of specific actions, and gives example of activities to be done by teachers and instructors throughout a course.

\section{References}

Barab, S., Kling, R., \& Gray, J. H. (2004). Designing for virtual communities in the service of learning. NY: Cambridge University Press.

Beldarrain, Y. (2006). Distance Education Trends: Integrating new technologies to foster student interaction and collaboration. Distance Education, 27(2), 139-153.

Berry, S. (2019). Teaching to connect: Community-building strategies for the virtual classroom. Online Learning, 23(1), 164-183. doi:10.24059/olj.v23i1.1425

Clark, C. J. (1998). Let your online learning community grow: 3 design principles for growing successful Email Listervs and online forums in educational settings. San Diego State University.

Duraku Z. and Hoxha L. (2020). The impact of COVID-19 on education and on the wellbeing of teachers, parents, and students: Challenges related to remote (online) learning and opportunities for advancing the quality of education. University of Prishtina

García aE. nd Weiss E. (2020). COVID-19 and student performance, equity, and U.S. education policy. Lessons from pre-pandemic research to inform relief, recovery, and rebuilding. Economic Policy institute.

Garrison, D. R., Anderson, T., \& Archer, W. (2000). Critical inquiry in a text-based environment: Computer conferencing in higher education. The Internet and Higher Education, 2(2-3), 87-105.

Garrison, D.R., Cleveland-Innes, M. \& Fung, T. (2010). Exploring causal relationships among teaching, cognitive and social presence: Student perceptions of the community of inquiry framework. Internet and Higher Education, 13(1-2), 31-36.

Garrison, D. R., \& Cleveland-Innes, M. (2005). Facilitating cognitive presence in online

learning: Interaction is not enough. American Journal of Distance Education, 19(3), 133148.

Garrison, D. R., \& Arbaugh, J. B. (2007). Researching the community of inquiry framework: Review, issues, and future directions. Internet and Higher Education, 10(3), 157-172.

Jacobs, J. (2003). Communication over exposure: The rise of blogs as a product of cybervoyeurism. Cited in J. B. Williams and J. Jacobs (2004). Exploring the use of blogs as 
learning spaces in the higher education sector. Australian Journal of Educational Technology, 20(2), 232-247.

Karahalios, K. \& Donath, J. (2003). Scale, form and time: creating connected sociable spaces. MIT Media Lab. Retrieved from http://persona.www.media.mit.edu/SMG

Khoo, E., \& Cowie, B. (2010). A framework for developing and implementing an online learning community. Journal of Open, Flexible and Distance Learning, 15(1), 47-59.

Lambert J. and Fisher J. (2013). Community of Inquiry Framework: Establishing Community in an Online Course. Journal of Interactive Online Learning . Volume 12, Number 1, Spring 2013 ISSN: 1541-4914

Mahdy M. (2020). The Impact of COVID-19 Pandemic on the Academic Performance Veterinary Medical Students. Front. Vet. Sci. 7:594261. doi: 10.3389/fvets.2020.594261

McMillan, D. W., \& Chavis, D. M. (1986). Sense of community: A definition and theory. Journal of Community Psychology, 14(1), 6-23.

Middleton K. (2020). The Longer-Term Impact of COVID-19 on K-12 Student Learning and Assessment. Educational Measurement: Issues and Practice, pp. 1-4

Oliveira, I., Tinoca, L., \& Pereira, A. (2011). Online group work patterns: How to promote a successful collaboration. Computers \& Education, 57, 1348-1357.

Phirangee, K., Demmans Epp, C., \& Hewitt, J. (2016b). Exploring the relationships between facilitation methods, students' sense of community and their online behaviours. Online Learning Journal, 20(2). http://dx.doi.org/10.24059/olj.v20i2.775

Pittaway, S. (2012). Student and staff engagement: Developing an engagement framework in a Faculty of Education. Australian Journal of Teacher Education, 37(4), 37-45.

Richardson, J. \& Swan, K. (2001) An examination of social presence in online learning: students' perceived learning and satisfaction, paper presented at the Annual Meeting of the American Educational Research Association, Seattle, WA

Short, J., Williams, E. \& Christie, B. (1976) The Social Psychology of Telecommunications, Toronto, Wiley.

Todd J. B. Blayone, Roland vanOostveen, Wendy Barber, Maurice DiGiuseppe and Elizabeth Childs (2017). Democratizing digital learning: theorizing the fully online learning community model. International Journal of Educational Technology in Higher Education (2017) 14:13 DOI 10.1186/s41239-017-0051-4

Tomas L., Lasen M. Field E., Skamp K. (2015). Promoting Online Students' Engagement and Learning in Science and Sustainability Preservice Teacher Education. Australian Journal of Teacher Education. Volume 40. Issue 11. Article 5.

$\mathrm{Tu}, \mathrm{C}$. and Corry M. (2001). Research in online learning Community. The George Washington University

UNESCO. (2020, March 4). Education: From disruption to recovery. UNESCO. Retrieved July 31, 2020, from https://en.unesco.org/covid19/educationresponse

Waycott, J., Sheard, J., Thompson, C., \& Clerehan, R. (2013). Making students' work visible on the social web: A blessing or a curse? Computers \& Education, 68, 86-95.

World Bank. (2020). How countries are using edtech (including online learning, radio, television, texting) to support access to remote learning during the COVID-19 pandemic 
Office of Learning Technologies. (1998). Models of Community Learning Networks in Canada. Ottawa, Ontario, Canada: Office of Learning Technologies by New Economy Development Group Inc.

Zappala J. (2012) Promoting Student Participation and Involvement in Online Instruction: Suggestions from the Front. Online Student Engagement Tools and Strategies. A mega Publication 